\title{
駅の階段における歩行者の密度と不安感の関係性の実験的把握 EXPERIMENTAL SURVEY OF RELATIONSHIPS BETWEEN WALKERS' DENSITY AND THEIR UNEASY FEELINGS ON STAIRS IN A STATION
}

\author{
山本昌和*, 吉村英祐** \\ Masakazu YAMAMOTO and Hidemasa YOSHIMURA
}

\begin{abstract}
In order to grasp the relationships between crowd densities and uneasy feeling of persons on stairs in railway stations, we conducted experiments which reproduced the high-density crowd starting to walk up and down the stairs in a mock-up station stairs. As a result, we obtained delay in starting to walk at various densities quantitatively and following 3 opinions.
\end{abstract}

1. When the density reaches about 4.0 persons/ $\mathrm{m}^{2}$, a majority of passengers may feel uneasy.

2. More attention must be paid to downward crowd staying on stairs than upward crowd because of its uneasy feeling.

3. A crowd must not be stayed on stairs in railway stations at a density of over 4.0 persons $/ \mathrm{m}^{2}$.

Keywords : Stairs, Crowd Density, Uneasy Feeling, Railway Stations, Experiments 階段，群集密度，不安感，鉄道駅，実験

\section{1.はじめに}

\section{1-1. 研究の目的と意義}

都市部に近い駅における朝夕のラッシュアワーには、列車の発着 に伴い駅のホームや階段などで旅客による群集流動が生じている。

特に輸送障害などにより列車の発着が遅延した際には、旅客が累 積的に駅構内に滞留しやすい。他路線への振替輸送が行われた際に は、迂回先となる駅に通常時を上回る旅客が集中することもある。 また、自然災害などの影響で広域にわたって運行が停止した場合、 運行の再開直後に一部の駅に多数の旅客が殺到し、ホームや階段な どが混乱すること1)もある。

一般に不特定多数の人が集まる施設では、群集事故を防止するた めの様々な対策が取られている。イベントのように事前に来場者数 が予想できる場合には、通例、開催者・交通事業者・警察・警備会 社等による事前協議が行われ、警備計画が立てられる 2),3,4)。駅でも 周辺で開催される花火大会等のイベントへの対応がこれに該当する。 しかし、ラッシュアワー等に発生する輸送障害等は予測が不可能で あり、群集規模の想定や十分な要員の配置が難しい。

イベント時における群集事故防止対策としては、入場規制や群集 の分断、情報の提供などの群集の特性を踏まえた制御が有効とされ ている 5),6)。その中の一つに、群集の過度な滞留や圧力を緩和する ため規制ラインを用いて群集流動を制止する方法があり、駅でも、
改札口や階段の入口で入場規制をおこなう事例 5)がみられる。 本来、群集は階段のように足元が不安定かつ群集事故が起きた際 に被害が大きくなりやすい場所ではなく、平らな部分に滞留させる べきである。しかし、実際の駅では階段の先にあるホーム上で群集 流が滞っている場合には、階段の入口で規制を実施したとしても階 段内に群集の一部が残されてしまう可能性がある。また、先に述心゙ た要員の関係から階段の出口でしか群集を規制できない可能性もあ る。このような場合、階段内が危険な状態とならないように群集の 密度を一定以下に抑える必要がある。

この上限となる密度に関して、著者らは、階段における群集歩行 で注意すべきは規制解除された群集が一斉に動き始めたときと考え ている注1)。特に駅の階段のように、一般的な建築物の階段に比べ幅 員が広く中間に手すりがない階段では、群集が物理的に収容できる 密度ではなく群集が不安を感じずに歩き始められるような密度を上 限とすべきであり、これらを明らかにする必要がある。

\section{1-2. 既往の研究と本稿の特色}

階段に収容できる群集の上限としては、避難安全検証法 7)で避難 経路等の部分に収容可能な避難者数を算定するための值が示されて いる。階段室での一人当たりの必要滞留面積を $0.25 \mathrm{~m}^{2} /$ 人すなわち 密度 4.0 人 $/ \mathrm{m}^{2}$ 注 2) としているが、その根拠は示されていない。

萩原 8)は米国における避難安全規定の変遷を明らかにするなかで

本論文は，日本建築学会大会学術講演会(関東)，2011年 8 月にて発表した内容に解析を加え，加筆修正したものである。

* 鉄道総合技術研究所建築 主任研究員 ·修士 (工学) Senior Researcher, Architecture, Railway Technical Research Institute, M. Eng.

** 大阪工業大学工学部建築学科 教授 ·博士 (工学) Prof., Dept. of Architecture, Faculty of Engineering, Osaka Institute of Technology, Dr. Eng. 
1913 年に制定されたニューヨークの工場法を紹介している。この工 場法では、区画された階段内に在館者を収容するという考え方に基 づき、一列のユニット幅を 22 インチとし、避難者が階段に一段お きに立つことを想定している。この考え方を参考に、建築基準法施 行令第 23 条第 1 項に基づいて標準的な階段を幅員 $1.2 \mathrm{~m}$ 、踏み面 $24 \mathrm{~cm}$ とし、一段おきに二人ずつが並んだときの密度を算定してみ ると密度は約 3.5 人 $/ \mathrm{m}^{2}\left(=0.29 \mathrm{~m}^{2} /\right.$ 人 $)$ 注 3) となる。また、Jake L. Pauls ${ }^{9}$ は実測調査に基づく避難階段内の密度と歩行速度の関係を

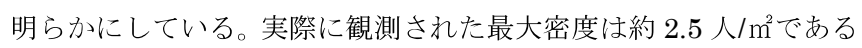
が、近似関数上で歩行速度が $0 \mathrm{~m} / \mathrm{sec}$ となる最大密度は約 3.7 人 $/ \mathrm{m}^{2 \text { 注 }}$ 4)となる。

新井ら ${ }^{10)}$ は静力学的なモデルを用いた計算から、階段で将棋倒し が生起しない人間の間隔を水平距離 $60 \mathrm{~cm}$ としている。しかし、こ の間隔は人間を棒状に近似したモデルに基づいており、実際の群集 への適用は慎重に行う必要がある。

心理的な観点から群集を定量評価した事例としては、毛利 11)らは 追い越しのしやすさの観点から密度による歩行路のサービス水準を 提案している。吉田ら ${ }^{12}$ は歩行速度による避難の円滑さの指標を提 案している。しかし、いずれも群集事故が生じるおそれのある高い 密度については、評価の適用範囲としていない。

また、大竹ら ${ }^{13)}$ は歩行者の個体専有面積分布を把握する実験のな かでアンケートを実施しており、平面床上での密度と心理量との関 係を示している。吉村および末原ら 14),15) は被験者実験を通じて群集 密度と体感圧力や呼吸のしやすさについてアンケート調查を実施し ている。貝辻ら ${ }^{16)}$ は、群集事故の事例分析に基づき群集の密度と危 険回避行動の関係を示している。しかし、いずれも平面における群 集を対象としており、階段における群集を対象としたものではない。 一方、駅の階段で生じ得る密度に関する既往の調查として、階段 内で静止した群集の密度を計測した例はないが、都築ら ${ }^{17)}$ は通勤時 の駅階段を歩行する群集で最大 $2.5 \sim 3.0$ 人 $/ \mathrm{m}^{2}$ と報告している。また、 戸川 ${ }^{18)}$ は降り階段での調査結果注5)を $2 \sim 6$ 人 $/ \mathrm{m}^{2}$ と記述したうえで 「流動をとめ、階段に収容し得る人数をきめようとするとき、 1 平 方米に 3 人とか 4 人とかいう低い密度ではない。 8 人 $/ \mathrm{m}^{2} て ゙ も$ 決して 危険ではない。(中略)階段の段面上の密度を、水平面積に直して、1 平方米につき 8 人までなら、安全に収容し得る」と記述している。 さらに、明石花火大会事故（2001 年）の調査報告書 19)では、事故 発生場所直近の階段において、踏み面 $30 \mathrm{~cm}$ 、有効幅員 $2.8 \mathrm{~m}$ の各段 に 4 人が立っていたと推計しているが注 6 )、この状況での群集密度 は 4.76 人 $/ \mathrm{m}^{2}$ となる。これらの事例や、何としても目的の列車に乗 りたい、少しでも早く他のホームに移動したいと欲する駅利用者の 心理を考慮すると、著者らは駅の階段で 4 人 $/ \mathrm{m}^{2}$ 超の密度が生じる可 能性は否定できないと考える。

本稿の特色は、これらの既往研究を参考に階段における群集の心 理を考虑した評価は十分なされていない注7)としたうえで、駅の階段 に滞留していた群集が一斉に歩き始める現象に主眼を置き、そのと きの密度と不安感の関係を実験的に明らかにする点にある。

\section{2. 研究の方法と実験の概要}

研究は、実験場の階段において再現した群集内の被験者を対象と して、歩き始めの際の足の動き、不安感および歩行開始の遅れに関
Table1 An outline of an experiment

\begin{tabular}{|c|c|}
\hline 実験日時 & 2010 年 9 月 25 日 (土) $10: 00 \sim 12: 00$ \\
\hline 実験場所 & ：(公財) 鉄道総合技術研究所 駅シミュレータ階段 \\
\hline 被験者 & ：18～55 歳 (平均 25 歳)の健常な一般男性 37 名 \\
\hline 実験方法 & (1)指定した配列で被験者を階段内に整列させる \\
\hline & (2)実験者の合図で被験者を 3 歩だけ昇降させる \\
\hline & (3)実験終了後, 被験者はアンケートに回答する \\
\hline \multirow{3}{*}{ 調査項目 } & (1) 歩き始める際の足の動きについて \\
\hline & (2) 歩き始める際の不安感について \\
\hline & (3) 歩き始める際の歩行行動のばらつきについて \\
\hline
\end{tabular}

Table2 Specifications of stairs

Width: $2700 \mathrm{~mm}$, Effective width between handrails: $2510 \mathrm{~mm}$ Difference of height: $3600 \mathrm{~mm}$, Altitude of landing: $+1650 \mathrm{~mm}$ Rise: $150 \mathrm{~mm}$

Tread: $300 \mathrm{~mm}$

Material: Granite, Finish: Jet and polish

Table3 Densities and arrangements of subjects

\begin{tabular}{|c|c|c|c|c|c|c|c|c|c|}
\hline $\begin{array}{c}\text { Density } \\
\left.\text { (person } / \mathrm{m}^{2}\right)\end{array}$ & 0.6 & 1.2 & 1.6 & 1.9 & 2.5 & 3.1 & 3.7 & 4.3 & 4.9 \\
\hline & 6 & 12 & 15 & 18 & 24 & 30 & 36 & 37 & 37 \\
\hline \multirow{5}{*}{$\begin{array}{l}\text { Arrangements } \\
\text { pattern of } \\
\text { subjects in } \\
\text { staircase }\end{array}$} & & & & 0 & 00 & 00 & 000 & 000 & $\overline{000}$ \\
\hline & 0 & 00 & 00 & 00 & 00 & 000 & 000 & \multirow{3}{*}{$\begin{array}{l}0000 \\
000 \\
000\end{array}$} & \multirow{2}{*}{0000} \\
\hline & \multirow[b]{2}{*}{$\bullet$} & & & $\bullet$ & \multirow{2}{*}{\multicolumn{2}{|c|}{$\bullet \bullet \bullet \bullet$}} & \multirow{2}{*}{$\bullet \bullet \bullet$} & & \\
\hline & & $-\bullet$ & $\bullet \bullet$ & & & & & & \multirow{3}{*}{$\begin{array}{lll}\bullet & \bullet \bullet \bullet \bullet \\
\bullet & \bullet \bullet \bullet \bullet \\
\end{array}$} \\
\hline & - & - $\bullet$ & -・ & $\bullet \bullet$ & \multicolumn{2}{|c|}{$\bullet \bullet \bullet \bullet \bullet$} & $\bullet \bullet \bullet$ & \multirow{3}{*}{$\mid \bullet \bullet \bullet$} & \\
\hline \multirow{3}{*}{$\begin{array}{c}\stackrel{\bullet}{\text { Measuring }} \\
\text { subjects }\end{array}$} & & & & $\bullet$ & $\bullet$ & $\bullet \bullet$ & $\bullet \bullet \bullet$ & & \\
\hline & $\bullet$ & $-\bullet$ & $\bullet \bullet \bullet$ & & - & $\bullet \bullet \bullet$ & $\bullet \bullet \bullet$ & & 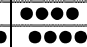 \\
\hline & & & & 0 & 00 & 00 & 000 & 000 & 0000 \\
\hline \multirow{3}{*}{$\begin{array}{c}O \\
\text { other subjects }\end{array}$} & O & 00 & 00 & & \multirow{2}{*}{\multicolumn{2}{|c|}{$\begin{array}{lllll}0 & 0 & 0 & 0 \\
0 & 0 & 0 & 0\end{array}$}} & 000 & \multirow{2}{*}{$\begin{array}{l}0000 \\
00\end{array}$} & \multirow{2}{*}{0} \\
\hline & & & & 0 & & & 000 & & \\
\hline & 0 & 00 & 000 & 0 & $\mathrm{O} 0$ & 000 & 000 & & \\
\hline
\end{tabular}

Table4 Questionnaire to subjects

Q1：階段をのぼる(おりる) ときの足の動きについてお聞きします. (1)合図に合わせて自分の意思で踏み出すことができた

(2)合図は聞こえたが，踏み出すことができず，

前の人が動くまで踏み出すことができなかった

(3)合図は聞こえたが，踏み出すことができず，

後の人が当たったので踏み出さざるを得なかった

(4)まったく踏み出すことができなかった

Q2：階段をのぼる(おりる)ときの気持ちについてお聞きします.

(1)不安 (2)どちらかといえば不安 (3)どちらでもない

(4)どちらかといえば安心 (5)安心

するアンケート調查および計測を行う方法とした。Table1 に実験の 概要を示す。

実験は、(公財)鉄道総合技術研究所内にある実物大模擬駅舎（以 降は、駅シミュレータと記す）の中にある、ホームからコンコース に上がる旅客用階段を模した階段において実施した。Table 2 に階段 の概要注8)を示す。実験では、高低差が $3.6 \mathrm{~m}$ ある階段のうち踊場か ら下の部分にあたる高低差 $1.65 \mathrm{~m}$ の部分を用いた。

群集の再現では、37名の被験者の一部もしくは全員を階段内に整 列させることで、0.6 4.9 人 $/ \mathrm{m}^{2} の$ 範囲にある 9 種類の密度の静止し た群集を再現した。また、被験者の配列辣9 は被験者の目前の一段が 必ず空いている状態、すなわち千鳥配置となるようにした。このよ うに被験者が階段に整列した状態を初期状態とする。Table 3 に初期 状態の密度と被験者数および配列の状況を示す。Table3 の○および ○は被験者を羁線は階段の踏み面を意味し、表上側が階段の上方向、 表下側が階段の下方向を表している。特に○は密度算定の対象とし 
た被験者を表している。

実験の試行は、実験者の合図とともに被験者には初期状態から 3 歩注 10)だけ階段を昇らせる（もしくは、降りさせる）方法とした。 被験者には「合図があっても動けない場合は、無理に動く必要はあ りません」「絶対に前の人を押さないで下さい。大変危険です」「皆 さんが、自然に歩く様子を撮影します。混雑した駅をイメージして、 普段通りに歩いて下さい」という教示を与えた。手摺の利用は被験 者の意思に任せたが、実際に手摺を利用寸る被験者はいなかった。 試行は同じ密度での昇降を 1 セットとし、4 4 セット実施した。ただ し、 0.6 人 $/ \mathrm{m}^{2}$ の条件は自由歩行となることが自明であることから 1 セットのみとした。実験上特に注意を要する密度注 11$)$ として 4.0 人 $\mathrm{m}^{2}$ を超える 4.3 人 $/ \mathrm{m}^{2} 、 4.9$ 人 $/ \mathrm{m}^{2}$ の条件については、被験者の安全を 確認しながら 1 セットのみ実施した。試行順は 1.2 人 $/ \mathrm{m}^{2}$ から 3.7 人 $/ \mathrm{m}^{2}$ の条件まで段階的に密度を高くすることで実施した。 0.6 人 $/ \mathrm{m}^{2}$ 、 4.3 人 $/ \mathrm{m}^{2} 、 4.9$ 人 $/ \mathrm{m}^{2}$ の条件は最後に実施した。

\section{3. 歩き始めにおける不安感に関するアンケート調査}

\section{3-1. アンケート調査の方法}

階段において群集が歩き始める際の足の動きおよび不安感につい ては、アンケート調查を実施した。被験者が自分の意思でうまく踏 み出せたかどうか、そのとき不安を感じたかどうかを聞いた。

密度 0.6 人 $/ \mathrm{m}^{2} 、 4.3$ 人 $/ \mathrm{m}^{2} 、 4.9$ 人 $/ \mathrm{m}^{2}$ については 1 セット目終了後 に、密度 1.2 人 $/ \mathrm{m}^{2} 、 1.6$ 人 $/ \mathrm{m}^{2} 、 1.9$ 人 $/ \mathrm{m}^{2} 、 2.5$ 人 $/ \mathrm{m}^{2} 、 3.1$ 人 $/ \mathrm{m}^{2} 、 3.7$ 人 $/ \mathrm{m}^{2}$ については 3 セット目終了後注 $\left.{ }^{12}\right)$ にアンケート調査を行い、歩 行開始する際の足の動きについては 4 段階評価で、不安感に対する 主観評価については 5 段階評価で回答させた。回答は用紙の選択肢 に印を付ける記入式とした。Table4 にアンケートの内容を示す。

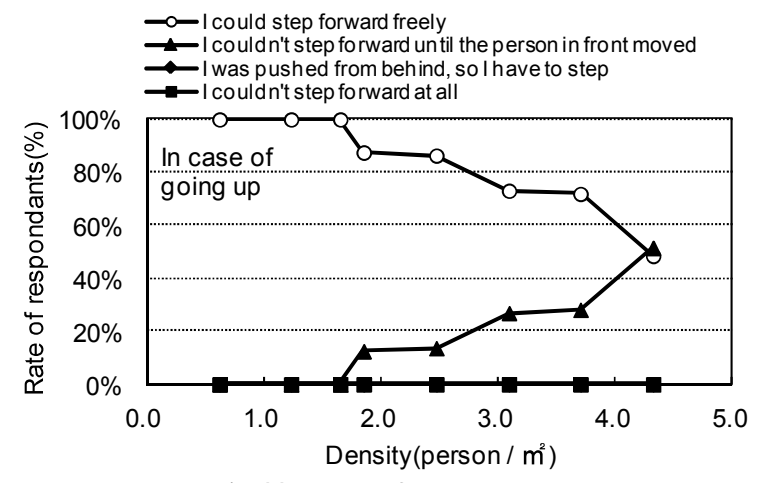

Fig.1 Variation of response about steps with density in case of going up

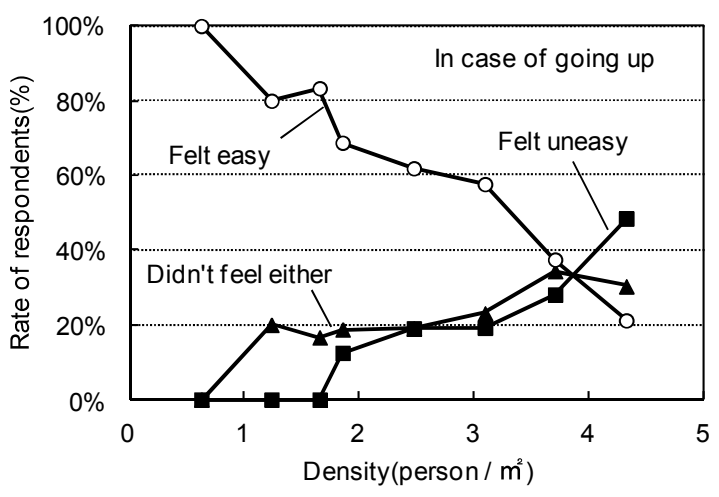

Fig.3 Variation of response about feeling with density in case of going up

\section{3-2.＼cjkstart歩き始めの際の足の動きと不安感}

Fig.1、Fig.2に足の踏み出しに関するアンケート結果注 13)を示す。 なお、密度 4.9 人 $/ \mathrm{m}^{2}$ の条件は追加試番注 14$)$ として実施したため、ア ンケート調査は行っていない。

昇りの場合、降りの場合ともに「後ろから押され踏み出さざるを 得なかった」「まったく踏み出せなかった」という回答は、降りの場 合にのみ見られた。「前が動くまで踏み出せなかった」という回答は、 昇りの場合、降りの場合ともに、密度 1.9 人 $/ \mathrm{m}^{2}$ のきにはじめて現 れ、密度が高くなるにつれて、回答者の割合が増えている。一方、

「自分の意思で踏み出せた」という回答は、密度が高くなるにつれ て、回答者の割合が減っている。そして、昇りの場合、降りの場合 ともに密度 4.3 人 $/ \mathrm{m}^{2}$ のき、「自分の意思で踏み出せた」という回 答と「前が動くまで踏み出せなかった」という回答の割合が逆転す る。特に降りの場合、密度 4.3 人 $/ \mathrm{m}^{2} て ゙ 「$ 前が動くまで踏み出せなか った」という回答が 6 割に達している。

次に、Fig.3、Fig.4に不安感に関するアンケート結果を示す。 アンケート結果の集計では、「安心」「どちらかといえば安心」と いう回答は「安心」として、「不安」「どちらかといえば不安」とい う回答は「不安」として集計している。

昇りの場合、降りの場合ともに「不安」という回答は密度 1.9 人 $\mathrm{m}^{2}$ のときにばめて現れ、密度 3.7 人 $/ \mathrm{m}^{2}$ 以上で大幅に増えている。 特に降りの場合、この傾向が顕著である。一方、「安心」という回答 は、密度が高くなるにつれて徐々に減る傾向が夕られ、密度 3.1 人 $\mathrm{m}^{2}$ 以上で大幅に減少している。そして、昇りの場合、降りの場合と もに密度 4.3 人 $/ \mathrm{m}^{2}$ のき、「安心」という回答と「不安」という回 答の割合が逆転する。これは足の踏み出し状況に関するアンケート 結果と同様の傾向である。特に降りの場合、密度 4.3 人 $/ \mathrm{m}^{2}$ で「不安」

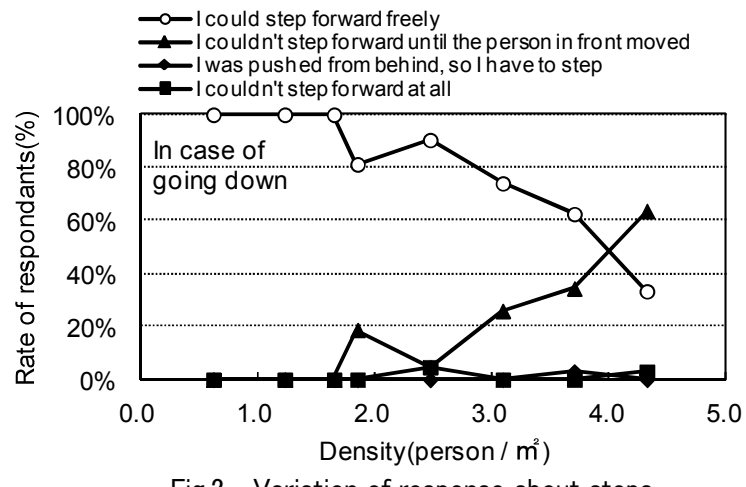

Fig.2 Variation of response about steps with density in case of going down

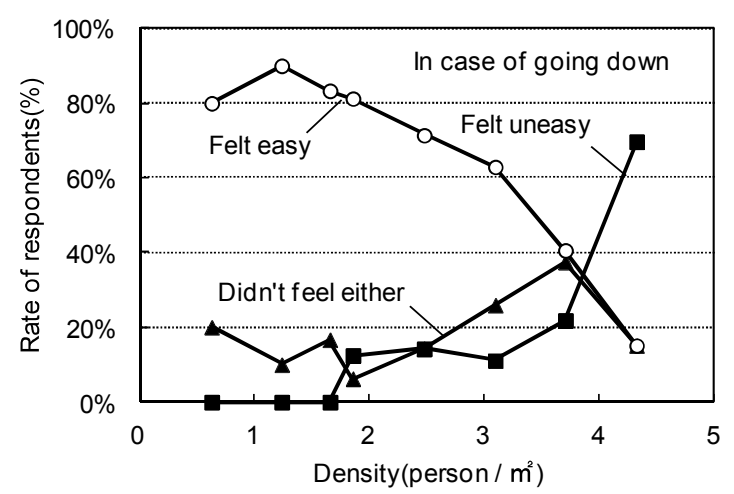

Fig.4 Variation of response about feeling with density in case of going down 


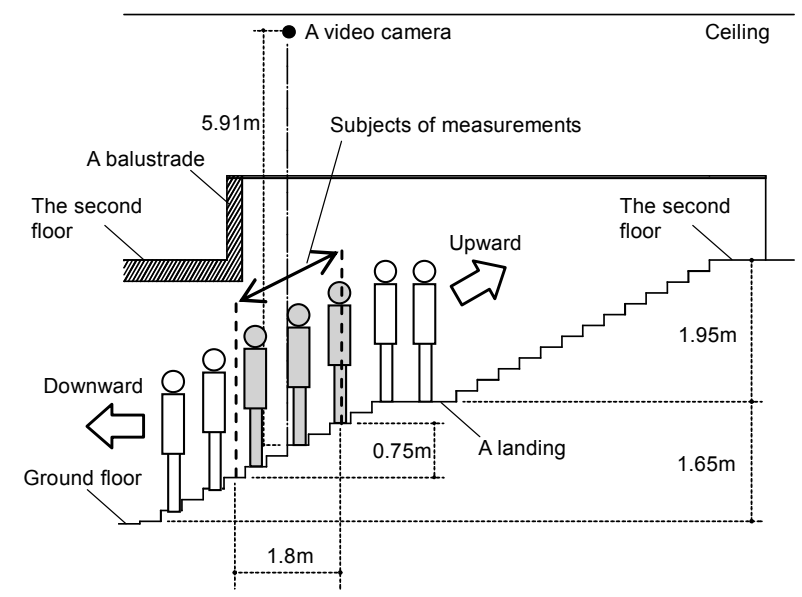

Fig.5 Section of stairs and subjects in the mock-up station

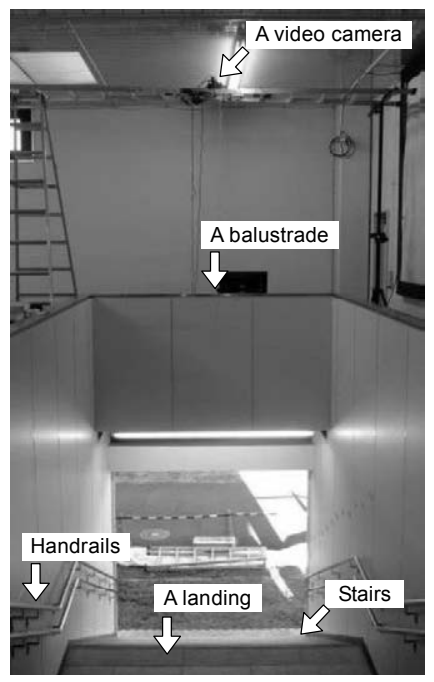

Photo1 Setting of a video camera in a staircase

いう回答が 7 割に達している。

\section{4. 歩行開始の遅れに関する調査}

\section{4-1. 計測の方法}

階段において、群集の歩き始めに生じる歩行開始の遅れを把握す るため、被験者の動きを計測した。なお、群集の足の動きを詳細に 捉えることは困難なため、頭部の動きを計測した。

計測は、Fig.5、Photo1に示すように、ビデオカメラ（SONY 製 HDR-CX520V) を実験場の階段の上方に設置することでおこなった。 また、計測範囲が最大となるように、ビデオカメラの位置は可能な 限り高い位置になるように調整した。このときのビデオカメラのレ ンズ中心と直下にある階段との距離注約 $5.9 \mathrm{~m}$ であった。

計測する範囲は画像の中心付近とし、ビデオカメラの画角から、 階段中央部の 6 段分（水平方向 $1.8 \mathrm{~m}$ 、鉛直方向 $0.75 \mathrm{~m}$ ）の範囲と した。Fig.5 に示すように、計測対象となる被験者は水平距離 $1.8 \mathrm{~m}$ の範囲に頭頂部が位置する被験者とする。なお、ビデオカメラの角 度の微調整を容易におこなうため、ビデオカメラの画像は接続した モニターにより確認できるようにし、ビデオカメラの角度は遠隔か ら操作できる電動雲台（Bescor 製 MP-101）を用いて調整した。

Photo2、Photo3 に示寸ように、被験者全員に頭頂部にターグッ

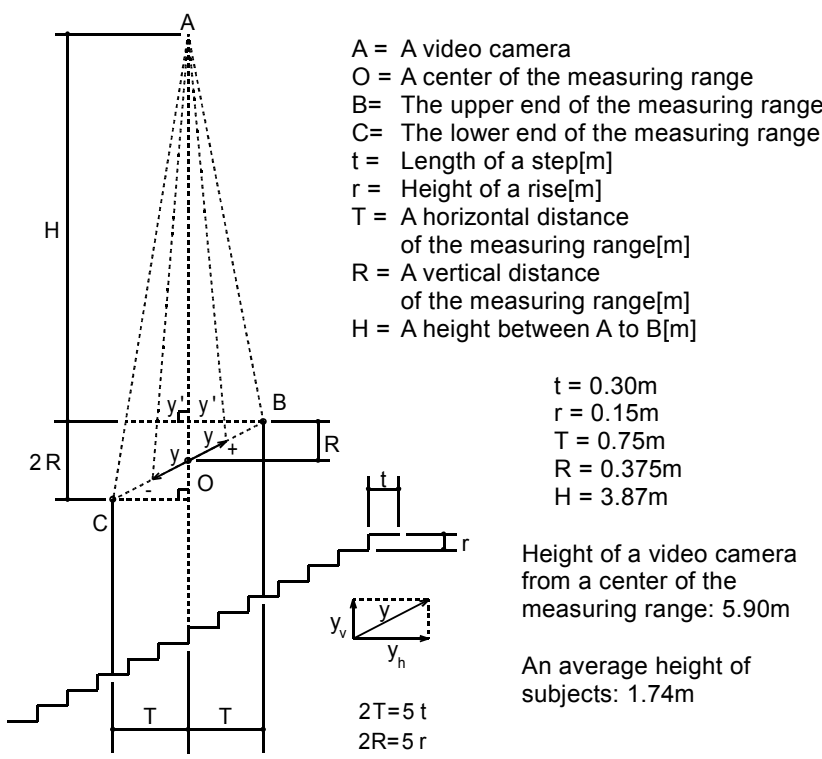

Fig.6 A coordinate axis for transformation from video images to positions of subjects

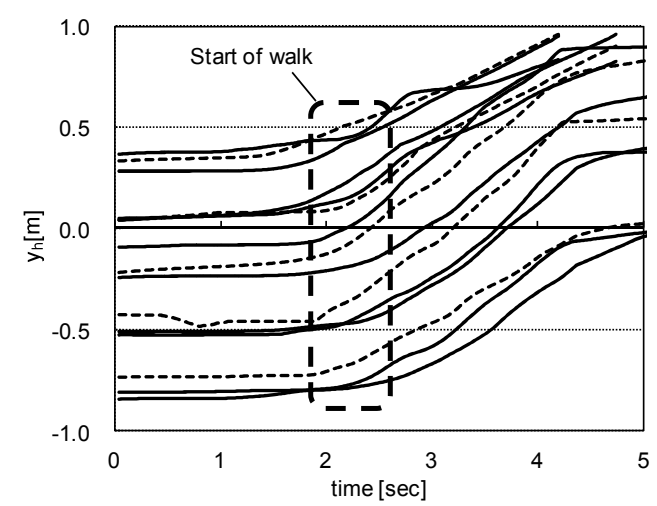

Fig.7 Variation of $y_{h}$ with time in case of 3.7 person $/ \mathrm{m}^{2}$

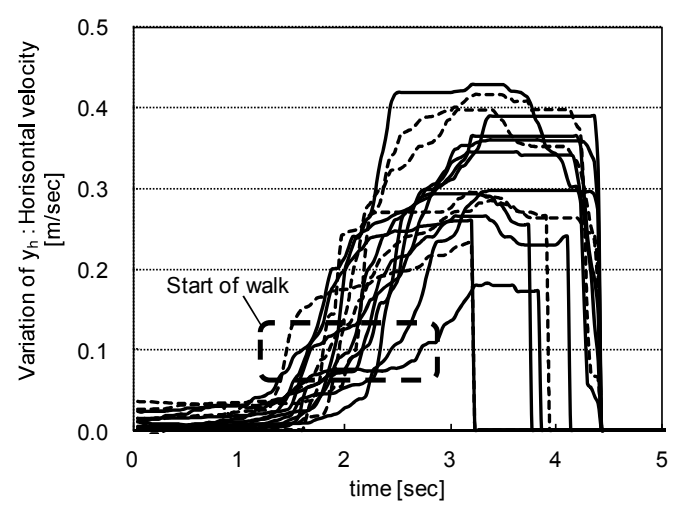

Fig.8 Variation of horizontal velocity with time in case of 3.7 person / $\mathrm{m}^{2}$

トマーク注 15)を張り付けた帽子を着用させ、頭部の動きを捕捉でき るようにした。また、ビデオカメラの画像から被験者が特定できる ように、被験者の肩の位置に上方に向けた番号札を張り付けた。

\section{4-2. 分析の方法}

得られた画像からターグットマークを自動的に読み取るソフトウ エア注 16)を用いて、基準点注 17)に対する被験者の位置を分析した。た だし、今回は群集の進行方向の動きのみに着目したため、左右方向 の座標については分析していない。 
得られた座標データは階段斜面を上部から鉛直下向きに撮影した 画像を基にしているため、階段の最上部と最下部では実際の距離と 画面上の距離とに差がある。そこで、Fig. 6 に示寸座標系を設定し てデータの補正をおこなった。

ある移動体が階段の踏み面より一定の高さを保ち、測定範囲中心 点 $\mathrm{O}$ から測定範囲端部 $\mathrm{C}$ または $\mathrm{B}$ まで移動するときの水平移動距 離、鉛直移動距離をそれぞれ $\mathrm{T}[\mathrm{m}] 、 \mathrm{R}[\mathrm{m}]$ とする。測定範囲中心の 直上にある点 $\mathrm{A}$ と点 $\mathrm{B}$ との高さの差を $\mathrm{H}[\mathrm{m}]$ とする。点 $\mathrm{O}$ と点 $\mathrm{B}$ および点 $\mathrm{C}$ を結ぶ任意の長さ $\mathrm{y}$ を持つベクトル $\mathrm{y}$ を考え、OB 方向 をプラス、 $\mathrm{OC}$ 方向をマイナスする。ベクトル $\mathrm{y}$ の水平成分を $y_{h}$ 、 鉛直成分を $y_{v}$ とする。また、点 $\mathrm{A}$ から見て、点 $\mathrm{B}$ と同一の水平面 上にベクトル $\mathrm{y}$ を投影したものをベクトル $\mathrm{y}^{\prime}$ とする。

$\mathbf{y}^{\prime}>0$ のとき、三角形の相似則から以下の関係が得られる。

$$
\frac{y^{\prime}}{H}=\frac{y_{h}}{H+R-y_{v}}
$$

階段の斜度は一定であることから、yh 表わすことができる。

$$
\begin{aligned}
& y_{v}=\frac{R}{T} y_{h} \text { より } \\
& y_{h}=\frac{T(H+R) y^{\prime}}{H T+R y^{\prime}}
\end{aligned}
$$

$\mathbf{y}^{\prime}<0$ のきも同様に、 $y_{h}$ は $\mathbf{y}^{\prime} を$ 用いて式(2)のように表わすこと ができる。

$$
\begin{aligned}
& \frac{y^{\prime}}{H}=\frac{y_{h}}{H+R+y_{v}} \\
& y_{h}=\frac{T(H+R) y^{\prime}}{H T-R y^{\prime}}
\end{aligned}
$$

ここで、点 $\mathrm{A}$ をビデオカメラレンズの中心、点 $\mathrm{B}$ 、点 $\mathrm{O}$ 、点 $\mathrm{C}$ は 被験者の頭頂部と考えた場合、y'は画像上での階段進行方向の移 動距離 $[\mathrm{m}]$ となる。階段の諸元や機器の設置条件から決まる定数項 は、Fig.6に示した通りである。

式(1)および(2)を基に得られた水平移動距離 $y_{h}$ の時間変化注 18) は、 単調増加（もしくは単調減少）する曲線として表される。Fig.7 に

Table5 Densities and delay time of starting in case of going up

\begin{tabular}{|c|c|c|c|c|c|c|}
\hline $\begin{array}{c}\text { Density } \\
\text { (person/m }{ }^{2} \text { ) }\end{array}$ & 1.2 & 1.6 & 1.9 & 2.5 & 3.1 & 3.7 \\
\hline \hline Sample & 14 & 28 & 29 & 36 & 44 & 53 \\
\hline $\begin{array}{c}\text { Mean } \\
(\mathrm{sec})\end{array}$ & 0.48 & 0.48 & 0.41 & 0.51 & 0.54 & 0.62 \\
\hline $\begin{array}{c}\text { Standard } \\
\text { deviation(sec) }\end{array}$ & 0.36 & 0.25 & 0.24 & 0.38 & 0.33 & 0.37 \\
\hline
\end{tabular}

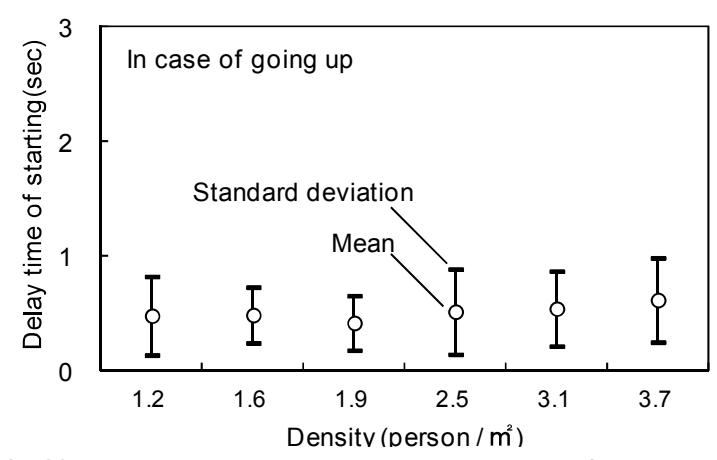

Fig.9 Variation on delay time with density in case of going up
密度 3.7 人 $/ \mathrm{m}^{2}$ で昇りの場合の例を示す。さらに、Fig.7 の破線で囲 んだ被験者全員が歩行を開始したと思われる時刻を詳細に把握する ため、1 sec あたりの $y_{h}$ の変化量 $[\mathrm{m}]$ 寸なわち水平速度 $[\mathrm{m} / \mathrm{sec}]$ をみる。 Fig. 8 に水平速度の時間変化の例を示す。ここで、水平速度が最初 に $0.1 \mathrm{~m} / \mathrm{sec}$ 以上となったときの時刻を各被験者の歩行開始時刻 [sec]と定義する。そのうち最初に歩行を開始したと判断される被験 者の移動開始時刻を基準としたときの、他の被験者の移動開始時刻 との差を歩行開始の遅れ[sec]と定義する。

\section{4-3. 密度による歩行開始の遅れの違い}

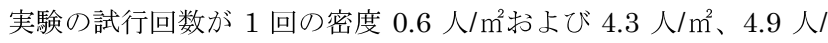
$\mathrm{m}^{2}$ の条件は再現性の観点から分析の対象とせず、密度 1.2 人 $/ \mathrm{m}^{2} 、 1.6$ 人 $/ \mathrm{m}^{2} 、 1.9$ 人 $/ \mathrm{m}^{2} 、 2.5$ 人 $/ \mathrm{m}^{2} 、 3.1$ 人 $/ \mathrm{m}^{2} 、 3.7$ 人 $/ \mathrm{m}^{2}$ の条件で得た有効 データ数注 19) と歩行開始の遅れの平均值を示したものが Table5、

Table6、これらをグラフで表したものが Fig.9、Fig.10である。

歩行開始の遅れにおける密度の影響を調べるため分散分析注 20)を おこなったところ、昇りの場合は有意でなかったのに対し降りの場

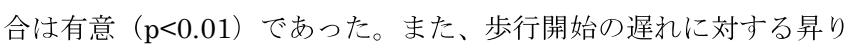
と降りの影響を調べるための各密度での結果に対し分散分析をおこ なったところ、密度 1.2 人 $/ \mathrm{m}^{2}$ 以外の密度で有意 $\left(1.6\right.$ 人 $/ \mathrm{m}^{2}: \mathrm{p}<0.05$ 、 1.9 3.7 人 $\left./ \mathrm{m}^{2}: \mathrm{p}<0.01\right)$ であった。

このことから、階段内の密度が 1.2 人 $/ \mathrm{m}^{2} \sim 3.7$ 人 $/ \mathrm{m}^{2}$ の範囲におい て、昇り方向の静止した群集では歩行開始の遅れは密度の影響を受 けにくいのに対し、降り方向の静止した群集では歩行開始の遅れは 密度の影響を受けやすく、密度が高くなるのに伴い歩行開始の遅れ は大きくなる傾向があることがわかった。また、密度が 1.6 人 $/ \mathrm{m}^{2} \sim$ 3.7 人 $/ \mathrm{m}^{2}$ の範囲において、昇り方向よりも降り方向の群集の方が歩 行開始の遅れは大きくなる傾向があることがわかった。

\section{5. 考察}

ここでは、不安感に関するアンケート調査および歩行開始の遅れ の計測の結果から、駅の階段において群集を滞留させる際に上限と なる密度について考察する。

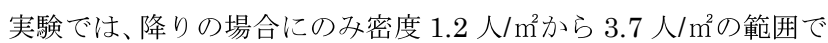

Table6 Densities and delay time of starting in case of going down

\begin{tabular}{|c|c|c|c|c|c|c|}
\hline $\begin{array}{c}\text { Density } \\
\left(\text { person/m }{ }^{2} \text { ) }\right.\end{array}$ & 1.2 & 1.6 & 1.9 & 2.5 & 3.1 & 3.7 \\
\hline \hline Sample & 14 & 20 & 24 & 32 & 40 & 53 \\
\hline $\begin{array}{c}\text { Mean } \\
\text { (sec) }\end{array}$ & 0.36 & 0.71 & 0.70 & 0.97 & 0.90 & 1.23 \\
\hline $\begin{array}{c}\text { Standard } \\
\text { deviation(sec) }\end{array}$ & 0.26 & 0.42 & 0.40 & 0.45 & 0.41 & 0.58 \\
\hline
\end{tabular}

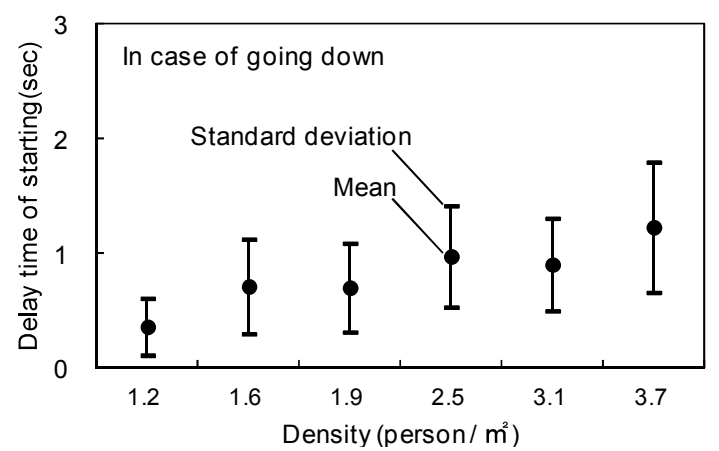

Fig.10 Variation on delay time with density in case of going down 
密度が高くなるほど歩行開始の遅れが大きくなる傾向がみられた。 また、昇りの場合に比心降りの場合の方が歩行開始の遅れが大きく なる傾向がみられた。このことから、階段内における昇り方向の群 集に比心゙降り方向の群集は、歩行開始時に何らかの抵抗を感じや寸 い可能性がある。今回の実験では抵抗の要因を明らかにするには至 っていない。被験者へのアンケートでは、昇りと降りの試番が終了 した後に昇りを降りについて続けてアンケートに回答させているた め、アンケート結果における昇りと降りの違いに関する解釈には注 意が必要であるが、階段を降りる場合には、昇る場合に比心゙、足の 動きに制約を感じた被験者、不安を感じた被験者ともに多い可能性 がある（Fig.3，Fig.4）。一方、過去の群集事故の事例 6)からも、群 集の一部で生じた転倒や躓きが事故のきっかけとなることが知られ ている。今回、降り方向の群集が歩行開始する際に見られた歩行開 始の遅れと群集内部での転倒や躓きの発生の関係は明らかではない が、階段における降り方向の群集では一歩を踏み出すのに躊躇する 状況が生じるなど、周囲と歩調を合わせにくい状況が歩行開始の遅 れや不安感に影響している可能性がある。また、群集の後方にいる 人々が群集中ほどで生じている歩行開始時の躊躇を知らずに無理に 歩行開始しようとした場合には前述のような転倒や躓きに繋がる恐 れもある。以上のことからも、降り方向の群集を階段内で滞留させ た場合には注意が必要であると考える。

次に、階段で群集を滞留させる際の上限となる密度について考え てみる。密度 4.3 人 $/ \mathrm{m}^{2} の$ とき半数以上の被験者が前の歩行者が動く まで足を踏み出せなかったと回答している（Fig.1，Fig.2）。このこ とから、密度が約 4.0 人 $/ \mathrm{m}^{2}$ 付近までは被験者が比較的自由に足を踏 み出せたものと推察できる。一方、心理面では、密度 3.7 人 $/ \mathrm{m}^{2} の$ と き安心と感じる被験者と不安と安心のどちらでもないと感じる被験 者の割合が拮抗していることから、密度が約 4.0 人 $/ \mathrm{m}^{2}$ 付近で大半の 被験者の心理が不安へと移行している可能性が高い(Fig.3, Fig.4)。 よって、密度約 4.0 人 $/ \mathrm{m}^{2}$ は群集が自由に足を踏み出すことができ る余地があり、大半の歩行者が不安を感じていない状態と推察でき る。そのため、階段においては、昇り降りにかかわらず密度約 4.0 人 $/ \mathrm{m}^{2}$ を超える状態で群集を滞留させるべきではないと考える。

また、今回の実験は、主として実験の安全確保のため健常な若い 男性被験者によって実施している。そのため、女性や子供、高齢者 等の多様な属性が含まれる群集では、より低い密度で不安を感じる 可能性が高い点に注意が必要である。

\section{6. まとめ}

本稿では、駅の階段に群集を滞留させた場合の、歩行開始時に感 じる不安や歩行行動のばらつきを調べる実験を行い、密度と不安感 および歩行開始の遅れの関係を明らかにした。以下に主な成果を示 す。

（1）自分の意思で足を踏み出しにくい被験者と不安を感じる被験者 が現れるのは、昇り降りにかかわらず密度が 1.9 人 $/ \mathrm{m}^{2}$ のきで あった。

（2）自分の意思で足を踏み出しにくい被験者と不安を感じる被験者 が半数を超えるのは、昇り降りにかかわらず密度が 4.3 人 $/ \mathrm{m}^{2}$ の ときであった。

（3）密度が $1.6 \sim 3.7$ 人 $/ \mathrm{m}^{2}$ のとき、歩行開始の遅れは昇りよりも降り
の場合で大きく、降りの場合では密度の上昇により歩行開始の 遅れが大きくなる傾向がみられた。

以上の成果から、駅の雑踏警備において、やむなく階段で群集を 滞留させるときに注意すべき点として、次のような知見が得られた。

（4）階段内の密度が約 2.0 人 $/ \mathrm{m}^{2}$ 前後に達するとき、群集の一部で不 安が生じる始め、密度が約 4.0 人 $/ \mathrm{m}^{2}$ 前後に達すると、群集の大 半で不安が生じる可能性がある。

（5）高い密度で静止した状態から階段を昇り始める群集に比べ、降 り始める群集では、不安を感じる歩行者が多い可能性がある。 そのため、特に降り階段に滞留させていた群集の規制を解除す る際には注意が必要と考える。

（6）階段内に群集を滞留させるとき、群集が自由に足を踏み出す余 地があり、大半に不安を感じさない密度は約 4.0 人 $/ \mathrm{m}^{2}$ と推察で きる。このことから、階段内には密度 4.0 人 $/ \mathrm{m}^{2}$ を超える密度で、 群集を滞留させるべきではないと考える。

（7）上記の知見は若い男性被験者による実験から得られた成果に基 づいており、不特定多数の歩行者がいる状況では、より低い密 度を上限とする必要があると考える。

今後の課題として、より多様な属性についても考慮した上限密度 を検討する必要がある。また、実際の雑踏警備では、動いている群 集を制止し密度が高くならないように規制するタイミングも重要で あると考えられることから、階段における密度上昇のメカニズムも 明らかにする必要があると考える。

注

注 1）群集事故には、(1）群集密度が高まることによる危険（2）高密度の群集 が統制なく動き出すことによる危険があると考えるが、本研究は(2)を対象 としている。(2)に類似した群集事故の事例として「二重橋事件(1954.1)」 6)があり、これは一般参賀に訪れた群集のロープ規制をゆるめた直後に起き た事故である。その他にも「大阪造幣局事件(1967.4)」19)のように門前に集 まった花見客の規制を解いた直後に生じた事故や、「大阪市新朝日ビル事 件(1971.12)」19)のように公開番組収録に集まった小中学生の階段下での規 制に失敗した事故がある。(1)は、後続する群集流を分断するなど動いてい る群集を制止する方法に大きく依存すると考えられることから、群集流の 制御方法を考えるうえでも重要な現象であると考えられる。

注 2）この密度は区画された階段室内に滞留できる避難者数を簡易に算出す るための定数であることから、静止状態の群集を想定したものと推察でき る。ただし、上記の目的から階段と踊り場の区別はなされていない。

注 3）この密度は階段に立つ避難者数の考え方に基づいていることから、踊り 場を含まない階段で静止状態にある群集の密度と考えられる。

注 4）この密度は踊り場を含まない階段の範囲で計測された結果に基づいて いること、歩行速度が $0 \mathrm{~m} / \mathrm{sec}$ となる密度をグラフより読みとっていること から、踊り場を含まない階段で静止状態にある群集の密度と考えられる。

注 5）観測状況の詳細に関する記載はないが、階段における群集流の密度の特 徵として、戸川は比較的長尺の階段（24 段、27 段）における密度には濃 淡があるという見解を述べており、昇り場合で上 8 段、中 8 段、下 8 段の

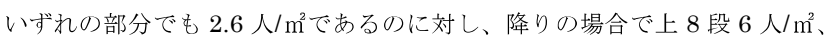
中 8 段 4 人 $/ \mathrm{m}^{2}$ 、下 8 段 2 人 $/ \mathrm{m}^{2}$ の実測結果が得られたとの記載がある。

注 6）階段の寸法は、明石歩道橋事故が発生した歩道橋の設計図面 ${ }^{20}$ による。

注 7）新井らも、「群集事故防止策の第 1 は、なんといっても群集を構成する 各個の心理制御である。おそらく、それは群集中に適当な空間を保持する ことによって確保される」と、心理面の重要性を述べている。

注 8）駅の階段に関するガイドライン 21)では、駅の階段の標準的な寸法とし て、蹴上げ $16 \mathrm{~cm}$ 程度以下、踏面 $30 \mathrm{~cm}$ 程度以上としている。そのため、 今回の実験で使用した階段（蹴上げ $15 \mathrm{~cm}$ 、踏面 $30 \mathrm{~cm}$ 、勾配 $1 / 2$ ）よりも 急勾配な駅の階段が存在する可能性もあるが、ガイドラインにて標準的と される範囲においては、上限となる勾配（1/1.875）に比較的近い勾配を持 
つ階段と位置付けられる。

注 9）被験者の配置にあたっては、密度算定範囲とする中央の 6 段における密 度が 0.5 人 $/ \mathrm{m}^{2} \sim 4.0$ 人 $/ \mathrm{m}^{2}$ の近傍で概ね 0.5 人 $/ \mathrm{m}^{2}$ の等間隔となるような被験 者数を決め、それらの被験者が階段内で均等な分布かつ被験者の目前の一 段が必ず空いている状態、寸なわち千鳥配置となるように配置を決めた。 この配置以外にも空いている段を設けない配置も考えられるが、最初に人 数を決めたうえで均等に配置する方法としたため、結果的に Table3 のよう な配置となった。密度の算定にあたっては、階段（幅 $2700 \mathrm{~mm}$ ）の中央部 6 段（踏み面 $300 \mathrm{~mm} \times 6$ 段 $=1800 \mathrm{~mm}$ ） に立つ被験者の人数と階段の水平 投影面積 $(2700 \mathrm{~mm} \times 1800 \mathrm{~mm})$ から算出した。階段幅については、手寸 りは被験者の肩よりも低い位置にあるため、群集の配列に影響を及ぼさな いと考え、手寸りを無視している。実際、今回再現した最大の密度 4.9 人/ $\mathrm{m}^{2}$ でも、1 段に並ぶ被験者は 4 人であり、被験者の腰が手すりに押しつけ られるような状況ではなかったことを確認している。

注 10）実験時の転倒事故を防止するため、高密度な状態での歩行を継続させ ないように配慮した。また、被験者には、足が踏み出せない場合は無理に 動かない、前方の被験者を絶対に押さないように教示をしている。本研究 では、歩き始めに感じる不安感の把握を目的としていることから、被験者 の歩行を 3 歩に限定しても問題ないと考えた。

注 11）避難安全検証法 7)における「滞留が継続する時間に対する心理的な要 因を考慮」した 1 人当たりの必要滞留面積の值に基づく密度は 4.0 人 $/ \mathrm{m}^{2}$ で あり、杂踏警備 2)でも、密度 4.0 人 $/ \mathrm{m}^{2}$ は水平路における「群集の安全確保 上の限界密度」とされていることから、今回の実験を安全におこなううえ で注意を要する密度と考えた。

注 12） 4 セット目は頭部の位置測定のための試行回数を増やすことを目的と しており、3セット目とは時間を空けて実施した。

注 13）群集の先頭および最後尾にいた被験者は実験におけるダミー条件とし て扱っており、その回答は分析するデータには含めていない。

注 14）当初の実験計画では、安全性を考慮して、最大密度は 4.3 人 $/ \mathrm{m}^{2}$ として いた。 4.3 人 $/ \mathrm{m}^{2}$ における被験者の様子から、全ての段に 4 人並べる 4.9 人 $\mathrm{m}^{2}$ の条件も十分安全に実施できると判断し、追加試番として実施した。

注 15）ターゲットマークとは、黄と黒のパターンで構成された円形のマーク であり、画像解析ソフトにより比較的精度良く捕捉することが可能である。 注 16）米 Glenallan Technology Inc. 製 View Point。このソフトでは、入力 した画像をコマ単位に分析することで、画像内のターグットマークの座標 を時刻毎のデータとして出力できる。今回は $30 \mathrm{~Hz}$ で分析をおこなった。

注 17）計測する範囲および解析の基準となる点をビデオカメラの画像に映し 込むため、長さ $1.74 \mathrm{~m}$ の棒の先端に被験者の頭頂部と同じターゲットマー クを取り付けたものを用意した。この棒を、計測範囲内の最下段および最 上段の踏み面の中心点に垂直に立てた状態で撮影をおこなうことで、基準 点を含む画像を取得した。棒の長さ $1.74 \mathrm{~m}$ とは、今回の被験者 37 名の靴 を履いた状態での平均身長から決定した。

注 18）被験者の頭部の細かな動きがノイズとしてデータに表れるのを防ぐた め、 $30 \mathrm{~Hz}$ で取得したデータを $1 \mathrm{~Hz}$ に平均化している。平均化にあたって は、ある時刻における対象物の $y_{h}$ は、その前後 $0.5 \mathrm{sec}$ の範囲にある母数 30 個の $y_{h}$ の值の最頻值（メジアン）とした。

注 19）計測は全ての試番に対しておこなっており、1 回の試番において有効 となるデータ数は、計測範囲内にターゲットマークが入っている被験者の 数から最初に歩行を開始した被験者 1 名を差し引いた数となる。また、歩 行開始時に頭部の動きが大幅に先行する被験者は、実験映像を確認しデー 夕から除外している。実験では実験条件である密度毎に 4 回の試行を実施 しており、4 回分のデータを足し合わせたものが全データ数となる。

注 20）密度を水準とした場合の各水準のデータ数が異なることから、平均值 の比較には $\mathrm{t}$ 検定ではなく一元配置の分散分析を用いた。

\section{参考文献}

1) 永田工, 宮嶋加菜子 : $3 \cdot 11$ バラバラ首都鉄道 JR 運休地下鉄は再開 大混 乱の夜検証一，朝日新聞夕刊, p.1, 2011.4.23

2）全国警備業協会編：雑踏警備業務の手引,pp.24 35, 2006.9

3）全国警備業協会編：雑踏警備業務の手引【上級】,pp.65 92, 2006.9

4) 兵庫県警察本部：雑踏警備の手引き, 2002.12

5) 岡田光正, 吉田勝行, 柏原士郎, 辻正矩: 建築と都市の人間工学, 鹿島出版

会, pp.68〜 72, 1977.6

6) 岡田光正 : 群集安全工学, 鹿島出版会, pp.15 72, 167 172, 2011.5
7）国土交通省住宅局建築指導課編：2001 年版避難安全検証法の解説及び計 算例とその解説, pp.31 60, 2005.3

8）萩原一郎：建築火災における避難安全規定の研究，博士論文, 1996.4

9) Pauls, J. L. : Building Evacuation: Research Findings and Recommendations, Fires and Human Behaviour, John Wiley \& Sons, pp.251-275, 1980

10）新井邦夫，丸井信雄:群集の流動と事故，総合都市研究，第 14 号，東京都 立大学都市研究所, pp.13 20,1981

11）毛利正光，塚口博司: 歩行路における歩行者挙動に関する研究，土木学会 論文報告集，第 268 号，土木学会, pp.99 108, 1977.12

12）吉田克之，峯岸良和，城明秀，竹市尚広，木村謙，佐野友紀 : 避難歩行流 の質の定量的評価方法に関する試案 マルチエージェント歩行者シミュレ ーター、SimTread の適用を通じて, 日本建築学会大会学術講演梗概集, A-2, pp.207 208, 2011.8

13）大竹宏之, 久保田一弘, 直井英雄 : 限定空間内の群集の個体専有面積分布 を把握するための基礎実験 個体領域の確保を考慮した室空間の規模計画 手法に関する研究その 4 , 日本建築学会大会学術講演梗概集, E-1, pp.991 992, 2009.8

14）吉村英祐，柏原士郎，横田隆司，飯田匡 : 人間の詰め込み実験に基づく群 集密度と群集圧の計測, 日本建築学会大会学術講演梗概集,E-1,pp.943 944, 2003.9

15）末原隆司，柏原士郎，吉村英祐，横田隆司，飯田匡 : 群集密度と群集圧の 関係に関する測定実験，日本建築学会近畿支部研究報告集，計画系(43), pp.297 300, 2003.5

16）貝辻正利，北後明彦：雑踏事故に至る高密度群集滞留下での群集波動現 象に関する研究 大規模イベント事例分析を通じて, 地域安全学会論文集, No.17, 地域安全学会, pp.21 29, 2012.7

17）都築知人，不破徹，青木俊幸，大戸広道，河合邦治 : 鉄道駅の流動評価に 関する研究 その 1 階段・エスカレーター, 日本建築学会大会学術講演梗概 集, E-1, pp.841 842, 1999.9

18）戸川喜久二 : 群衆と密度, 都市計画, vol.73, pp.17 19, 1972.11

19）明石市民夏まつり事故調查委員会 : 第 32 回明石市民夏まつりにおける花 火大会事故調查報告書, p94, 2002.1

20）兵庫県明石市: 朝霧連絡歩道橋取付部及び橋面工整備工事竣工図 第 4 葉 (平面詳細図・断面詳細図, 縮尺 1:50), 2001

21）国土交通省総合政策局安心生活製作課監修：公共交通機関の旅客施設に 関する移動等円滑化整備ガイドライン，旅客施設編，交通エコロジー・モ ビリティ財団, p.47, 2013.10 


\title{
EXPERIMENTAL SURVEY OF RELATIONSHIPS BETWEEN WALKERS' DENSITY AND THEIR UNEASY FEELINGS ON STAIRS IN A STATION
}

\author{
Masakazu YAMAMOTO* and Hidemasa YOSHIMURA** \\ * Senior Researcher, Architecture, Railway Technical Research Institute, M. Eng. \\ ** Prof., Dept. of Architecture, Faculty of Engineering, Osaka Institute of Technology, Dr. Eng.
}

This paper presents a study of crowd safety on stairs in stations. A large numbers of passengers walk through a concourse, stairs and a platform to get on and off trains during rush hours in large stations. A crowd tends to be built up in a station if transport disorder causes train delay or operation suspension. Crowds also will be built up in a station when train operations are resumed after a long-time suspension caused by a disaster that influences on the extensive urban area such as an earthquake, a heavy rain, a power failure, etc. Then platforms and stairs are covered by crowds who hurry to their office or home. It is important in those cases that station staffs appropriately control the crowd by proper guidance, information, etc. When some large events are given, the organizer, the police and the guard company make detailed plans to prevent crowd issues. But it is difficult for station to anticipate and plan thoroughly for transport disorder and crowd accident at rush hours. Therefore, in this study we focus on the capacity of stairs when station staffs have to make passengers stay on stairs by controlling them.

The aim of this study is to clarify the density at which the crowd can stay on stairs without uneasy feeling. We consider that the safe crowd capacity of stairs must be settled from the psychological aspect of the crowd, as well as the physical aspect. So we made a point of the behavior of the crowd starting to walk on stairs, on the assumption that it is more dangerous for the still crowd to start walking on stairs, than for the crowd to keep walking.

In order to grasp the relationships between crowd densities and uneasy feelings, we conducted reproductive experiments of high-density crowd starting to go up or down stairs in a mock-up station stairs. The scene of the experiment is shown in Fig.5 and Photo2. Questionnaire surveys were conducted to grasp the variation of uneasy feeling. Further, we measured the movement of subjects' heads to clarify the difference of time to start walking in the crowd. Crowd densities reproduced and the arrangement of subjects are as shown in Table3.

As a result, we quantitatively obtained the variation of uneasy feeling and delay time in the high-density crowd starting to walk. These characteristics are as follows. (1) A part of subjects started to feel uneasy when they go up or down at a density of 1.9 persons $/ \mathrm{m}^{2}$. (2) A majority of subjects felt uneasy when they go up or down at a density of 4.3 persons $/ \mathrm{m}^{2}$. The percentage of subjects who felt uneasy reached 70 particularly in the case of going down. (3) The delay time of starting to go down is larger than to go up. And the delay time increases with the increase in density.

From these results, we obtained the following views on the crowd capacity of stairs. (4) When the density reaches about 4.0 persons $/ \mathrm{m}^{2}$, a majority of crowds may feel uneasy. (5) More attention must be paid to downward crowd staying on stairs than upward crowd because of its uneasy feeling. (6) A crowd in a station must not be stayed on stairs at a density of over 4.0 persons $/ \mathrm{m}^{2}$. (7) A crowd including females, children or the aged must be stayed on stairs at lower density. 